\title{
Characterization of Pyrolysis Products Obtained During the Preparation of Bio-Oil and Activated Carbon
}

\author{
Rosa Miranda, César Sosa, Diana Bustos, \\ Eileen Carrillo and María Rodríguez-Cantú \\ Universidad Autónoma de Nuevo León \\ México
}

\section{Introduction}

Nowadays, energy security and sustainable development are two major challenges encountered by the world. Renewable energy should be studied extensively to explore new technologies and in order to maintain secure energy sources for sustainable development, considering the fact that the energy demand is increasing, depleting fossil fuel reserves, with increasing populations and economic development.

Biomass is one of the most important renewable energy sources and is considered an alternative to fossil fuels. Biomass thermo chemical conversion processes including pyrolysis, combustion, gasification and liquefaction are employed for power generation and production of liquid biofuels, chemicals and charcoal, which can be used as activated carbon. Biomass is mainly composed of carbon; recently this property has been very attractive for the purpose of producing functional carbon materials, which have relevant economic and environmental implications.

Biomass resources include wood from plantation forests, residues from agricultural or forest production, and organic waste by-products from industry, domesticated animals, and human activities. The chemical energy contained in the biomass is derived from solar energy using the process of photosynthesis. This is the process by which plants take in carbon dioxide and water, using energy from sunlight, convert them into sugars, starches, cellulose, lignin etc., and finally oxygen is produced and released.

Pyrolysis of biomass is a promising method for simultaneous production of activated carbon, bio-oil and gaseous fuels and other valuable chemicals, while the almost simultaneous pyrolysis and gasification of the fuel result in formation of solid product with high surface area and well-developed porous structure (Nickolov \& Mehandjiev, 1995; Mehandjiev et al., 1997). Pyrolysis is the thermal destruction of organic macromolecules in the absence of oxygen in small molecules. The destructed portion comprises a high energy 
content and significant organic content, which leads to the possibility of energy extraction as well as the production of activated carbon and chemicals from biomass (Prakash \& Karunanithi, 2008).

As stated in previous chapters, activated carbons are carbonaceous materials with a high surface area and porous structure, sometimes described as solid sponges (Abdel-Nasser \& El-Hendawy, 2005). The large surface area results in a high capacity for adsorbing chemicals from gases or liquids. Activated carbons are versatile adsorbents with a wide range of applications such as adsorbents for treatment and purification of water, air as well as various chemical and natural products (Abdel-Nasser \& El-Hendawy, 2005; Budinova et al., 2006). The increasing use of activated carbon is due to the necessity of environmentally friendly processes and also for material recovery purposes.

Chapter 1 shows that different types of biomass materials and waste products have been studied for activated carbon production. These precursors include wood (Ahmad et al., 2006), coal (Lozano-Castello et al., 2005), nut shells (Lua et al., 2004), husks (Baquero et al.,2003), and agricultural by-products (Abdel-Nasser \& El-Hendawy, 2005; Durán-Valle et al., 2005; Budinova et al., 2006). In addition to the use as an adsorbent, high porosity carbons have been recently applied in the manufacture of high-performance layer capacitors. Because of the introduction of rigorous environmental regulations and the development of new applications, the demand for porous carbons is expected to increase progressively (Sircar et al., 1996). Applications of pyrolysis products have some disadvantages due to the high degree of heterogeneity in their form and composition. Characteristics of these products depend on the operating conditions and the type of biomass used, so it requires more knowledge of the conversion process.

Pyrolysis is discussed here to improve the valorisation of two Mexican typical agricultural wastes for energy and carbon activated production. The product characteristics, their relative proportions in the gas/liquid/solid phases and the process energy requirements depend upon the input material and the process conditions. Therefore, the goal of this chapter is to describe the conversion of waste biomass into activated carbon. Waste biomass like orange peel and pecan nut shell is converted thermally in one step. First, the biomass undergoes a pyrolysis process at $600{ }^{\circ} \mathrm{C}$ in nitrogen atmosphere. The gaseous and liquid pyrolysis products were collected as bio-oil, and then they can be used as fuel either for heating the facilities or for electricity production.

\section{Experimental method for biomass pyrolysis}

Bench scale experiments were carried out in a pyrolysis system with controlled temperature and a semi-batch stainless steel reactor. The schematic diagram of the process is illustrated in Figure 1. The reactor has a volume of three litters, and is externally heated by an electrical furnace. Pyrolysis experiments are normally performed with approximately $400 \mathrm{~g}$ of feedstock. The sample was placed inside the reactor and heated at $600{ }^{\circ} \mathrm{C}$ for one hour. The gases and vapours generated during pyrolysis pass through a condensation train, which consists of four Pyrex traps. The remaining non-condensable gases are collected and stored in a plastic sampling bag with a valve for future chromatography analysis. Pyrolysis product yields are 
determined by weighing the char and bio-oil. Non-condensable gases yield is calculated by the mass difference. Pyrolysis end temperatures were fixed at 600,700 and $750{ }^{\circ} \mathrm{C}$. All experiments were performed under nitrogen atmosphere using a flow of $60 \mathrm{ml} / \mathrm{min}$.

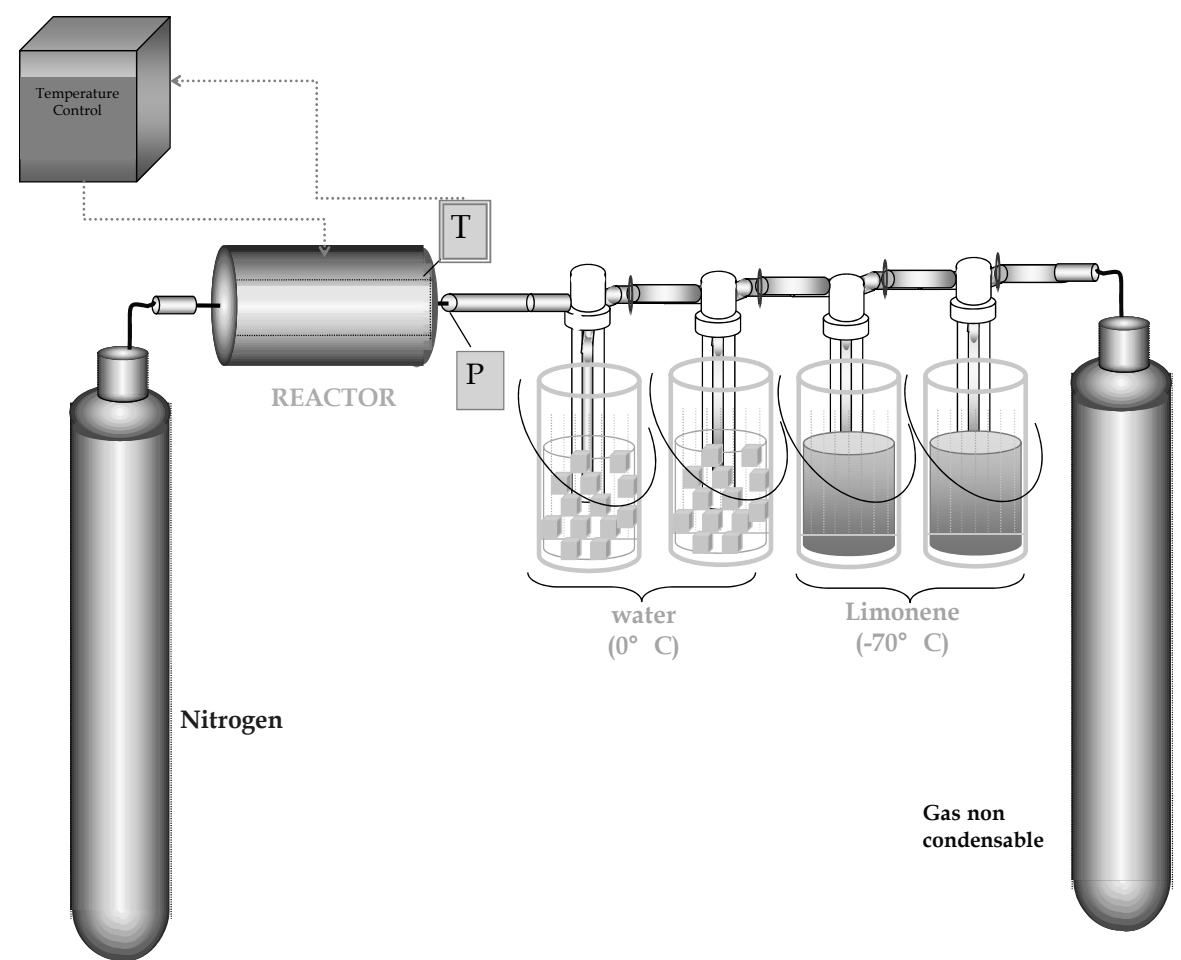

Figure. 1. The schematic diagram of the pyrolysis batch system. T-Thermocouple and PPressure transductor.

\subsection{Raw material}

Two types of biomass were used in the present study. Specifically, pecan nut shell was used as feedstock, obtained from a trading industry of nut located in the city of Torreon, Coahuila in the northeast of México. The orange peel sample was was obtained from a juice processing factory in Monterrey, N.L., México. For easy storage and management, the samples were cut into small pieces of an average area of $2 \mathrm{~cm}^{2}$ and dried in an air-tunnel at room temperature for the orange peel and in a stove for the case of nut shell.

The elemental analysis of the major components was carried out in a Perkin-Elmer 2400. Moisture was determined by the weight loss at $105^{\circ} \mathrm{C}$ for $12 \mathrm{~h}$ and is expressed as a weight percentage of the dry matter. The calorific value was obtained in a calorimetric bomb from Parr (model 1341) and it can be expressed in two forms: the gross or higher heating value (HHV) and the net calorific value or lower heating value (LHV). HHV was determined using the calorimeter bomb, through the determination of the temperature difference before 
and after the occurrence of the sample combustion. LHV is obtained by subtracting the latent heat of vaporization of the water vapor formed by the combustion from the gross or higher heating value.

Ash residue was obtained by thermogravimetry (ASTM D5630 method). Proximate analysis was performed using a thermogravimetric analyzer. The sample was heated under an inert atmosphere at $850{ }^{\circ} \mathrm{C}$ and the weight loss during this step is the volatile matter (VM). The gas atmosphere is then switched to air to burn off fixed carbon (FC), while the temperature is reduced to $800^{\circ} \mathrm{C}$. Finally, any residue left after the system is cooled to room temperature and is considered ash.

\subsection{Product Characterization}

All the collected liquid fractions were characterized by GC/MS using an Agilent Technologies 6890 GC coupled to a 5973 MS. The capillary column was a HP-1, $30 \mathrm{~m}$ large, $0.025 \mathrm{~mm}$ ID, and helium UHP as the carrier gas. A NIST library in the GC-MS chemstation is used as reference to identify the components of the bio-oil. The last solid residue from the different pyrolysis runs was analysed by elemental analysis. Figure 1 illustrates the schematic diagram of the process, as well as the places where the temperature and pressure were measured and recorded every 30 seconds by means of a data acquisition system.

\section{Results of biomass pyrolysis}

\subsection{Biomass Properties}

Biomass is a complex solid material constructed from oxygen-containing organic polymers produced by natural process. The major structural chemical components with high molar masses are carbohydrate polymers and oligomers (65-75\%) and lignin (18-35\%). The major constituents consist of cellulose (a polymer glucosan), hemicelluloses (which are also called polyose), lignin, organic extractives and inorganic minerals.

The weight percent of cellulose, hemicellulose, and lignin varies in different biomass species. Other biomass compounds are lipids, proteins, simple sugars and water. The pyrolytic chemistry differs sharply between plant carbohydrate polymers from fossil feeds due to the presence of large amounts of oxygen (Mohan et al., 2006). The elemental analysis information of the sweet orange dry peel and pecan nut shell in comparison with other results reported in literature are given in Table 1 . The contents of $\mathrm{C}, \mathrm{H}, \mathrm{O}$ and $\mathrm{N}$ vary significantly for different types of biomass. The sulphur content in the orange peel is lower than the corresponding to fossil fuels like bituminous coal $(4.7 \%$, wt.) and could be considered as a renewable fuel with lower emission of SOx, which causes pollution and climate change (Sudiro \& Bertucco, 2007). Biomass has higher contents of $\mathrm{O}$ and $\mathrm{H}$ and a lower $\mathrm{C}$ content than those reported for fossil fuels. 


\begin{tabular}{|c|c|c|c|c|c|c|c|c|}
\hline Biomass & $\mathrm{C}$ & $\mathrm{H}$ & $\mathrm{O}$ & $\mathrm{N}$ & $S$ & $\mathrm{H} / \mathrm{C}$ ratio & $\begin{array}{l}\mathrm{O} / \mathrm{C} \\
\text { ratio }\end{array}$ & Reference \\
\hline Almond shell & 47.63 & 5.71 & 44.48 & $\mathrm{a}$ & $\mathrm{a}$ & 1.44 & 0.700 & Balci et al. (1993) \\
\hline Coconut shell & 47.97 & 5.88 & 45.57 & 0.30 & $\mathrm{a}$ & 1.47 & 0.712 & Fagbemi et al. (2001) \\
\hline Corn cob & 43.04 & 6.32 & 49.26 & 1.02 & $\mathrm{a}$ & 1.76 & 0.858 & Ren et al. (2009) \\
\hline Corn Cob & 42.90 & 6.40 & 49.22 & 0.60 & $\mathrm{a}$ & 1.79 & 0.860 & Yanik et al. (2007) \\
\hline $\begin{array}{l}\text { Cottonseed } \\
\text { cake }\end{array}$ & 49.29 & 5.59 & 38.67 & 1.23 & a & 1.36 & 0.588 & Özbay et al. (2001) \\
\hline $\begin{array}{l}\text { Groundnut } \\
\text { shell }\end{array}$ & 48.27 & 5.70 & 39.40 & 0.80 & a & 1.42 & 0.612 & $\begin{array}{l}\text { Raveendran et al. } \\
(1996)\end{array}$ \\
\hline Hazelnut shell & 49.94 & 5.65 & 42.81 & 0.27 & $\mathrm{a}$ & 1.36 & 0.643 & Balci et al. (1993) \\
\hline Hazelnut shell & 50.08 & 5.13 & 41.99 & 1.38 & $\mathrm{a}$ & 1.23 & 0.629 & Demirbas (2006) \\
\hline Hazelnut shell & 50.34 & 5.84 & 42.33 & 0.40 & $\mathrm{a}$ & 1.39 & 0.631 & Bonelli et al. (2003) \\
\hline Orange peel & 39.7 & 6.20 & 53.0 & 0.46 & 0.60 & 1.87 & 1.001 & Miranda et al. (2009) \\
\hline Peanut shell & 46.59 & 6.00 & 43.65 & 2.06 & $\mathrm{a}$ & 1.55 & 0.703 & Bonelli et al. (2003) \\
\hline Pecan nutshell & 47.3 & 6.40 & 45.5 & 0.70 & $\mathrm{a}$ & 1.62 & \begin{tabular}{|l|l|}
0.721 \\
\end{tabular} & Present work \\
\hline Pine needles & 45.81 & 5.38 & 46.11 & 0.98 & $\mathrm{a}$ & 1.41 & 0.755 & Safi et al. (2004) \\
\hline Rice Straw & 45.14 & 5.85 & 47.73 & 0.62 & $\mathrm{a}$ & 1.56 & 0.793 & Ren et al. (2009) \\
\hline Rice Straw & 43.68 & 5.70 & 39.72 & 0.97 & $\mathrm{a}$ & 1.57 & 0.682 & Xiao et al. (2010) \\
\hline Sunflower shell & 47.40 & 5.80 & 41.40 & 1.40 & $\mathrm{a}$ & 1.47 & 0.655 & Demirbas (2006) \\
\hline Walnut shell & 50.58 & 6.41 & 41.21 & 0.39 & $\mathrm{a}$ & 1.52 & 0.611 & Onay et al. (2004) \\
\hline Wheat Straw & 48.32 & 2.54 & 48.21 & 0.82 & $\mathrm{a}$ & 0.63 & 0.748 & Ren et al. (2009) \\
\hline $\begin{array}{l}\text { Xylan from } \\
\text { oat spelts }\end{array}$ & 43.55 & 5.77 & 46.33 & 4.00 & 0.24 & 1.59 & 0.798 & Miranda et al. (2009) \\
\hline Sigmacell & 35.45 & 5.54 & 57.87 & 0.82 & 0.32 & 1.88 & 1.224 & Miranda et al. (2009) \\
\hline Kraft lignin & 41.06 & 6.88 & 50.98 & 0.65 & 0.43 & 2.01 & 0.931 & Miranda et al. (2009) \\
\hline
\end{tabular}

Table 1. Elemental Analysis of different type of biomass wastes reported in literature.

On the other hand, biomass contains between 36-52\%, wt. carbon while the coal carbon content is about 75-90\%, wt. This means that the heating value of biomass is lower due to the lower energy contained in carbon-oxygen and carbon-hydrogen bonds than those reported for carbon-carbon bonds (Baxter, 1993).

An essential parameter to compare biomaterials or products derived from thermal processes is the elemental composition. The significance of the $\mathrm{O}: \mathrm{C}$ and $\mathrm{H}: \mathrm{C}$ ratios of a material on the calorific value can be illustrated using a Van Krevelen diagram, see Figure 2 (Van-Krevelen, 1950). The values for $\mathrm{H} / \mathrm{C}$ and O/C depend on feedstock, operating conditions, any further treatment methods and water content. Figure 2 shows these ratios for various biomasses and products. For example, these parameters may vary significantly for different biomasses and they include: methanol $(\mathrm{H} / \mathrm{C}, \mathrm{O} / \mathrm{C})=(4,1)$, methane $(4,0)$, to various biomass sources $(1.2-$ 1.7, 0.6-0.8), pyrolysis oils (1.6, 0.35), pyrolytic carbon $(0.13,0.2)$ (Miranda et al., 2009), anthracite $(0.4,0.01)$, lignite $(1.14,0.24)$ and activated carbon $(0.30,0.04)$. A typical data for diesel/gasoline is oxygen content close to zero and $\mathrm{H} / \mathrm{C}$ ratio of 1.5 to 2 . 


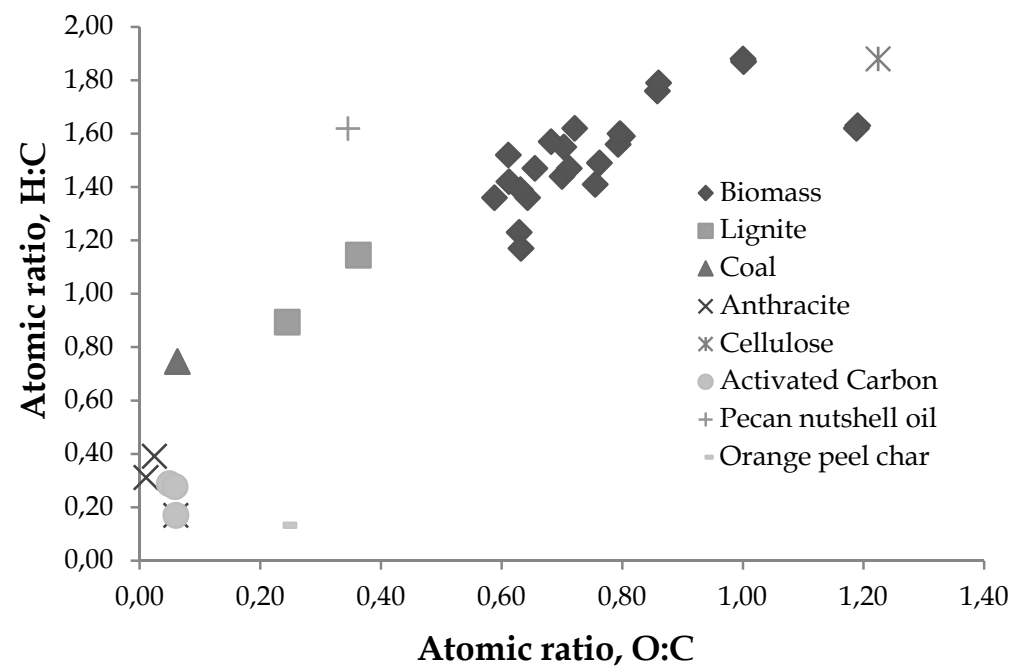

Figure 2. Van-Krevelen diagram of various materials.

\begin{tabular}{|l|l|l|l|l|l|l|}
\hline Biomass & $\begin{array}{l}\text { Volatile } \\
\%, \text { wt. }\end{array}$ & $\begin{array}{l}\text { Moisture } \\
\%, \text { wt. }\end{array}$ & $\begin{array}{l}\text { HHV } \\
\text { kJ/kg }\end{array}$ & $\begin{array}{l}\text { FC } \\
\%, \text { wt. }\end{array}$ & $\begin{array}{l}\text { Ash } \\
\%, \text { wt. }\end{array}$ & Reference \\
\hline Orange peel & 77.73 & 9.20 & 16829 & 13.07 & 2.94 & $\begin{array}{l}\text { Miranda et al. } \\
(2009)\end{array}$ \\
\hline Pecan nutshell & 60.00 & 10.28 & N.D. & 29.72 & 0.93 & Guevara (2009) \\
\hline P. yezoensis & 36.8 & 9.20 & 10600 & 22.10 & 31.30 & Li et al. (2011) \\
\hline Wheat Straw & 76.00 & 8.10 & 18910 & 16.40 & 7.60 & $\begin{array}{l}\text { Giuntoli et al. } \\
\text { (2009) }\end{array}$ \\
\hline Rice husk & 62.43 & 7.16 & 13620 & 14.98 & 15.43 & Pütü et al. (2004) \\
\hline Sugarcane bagasse & 84.83 & $\mathrm{a}$ & 20000 & 13.30 & 1.89 & Das et al. (2004) \\
\hline Lemon peel & 69.84 & 9.09 & 17734 & 17.22 & 3.85 & $\begin{array}{l}\text { Heikkinen et al. } \\
\text { (2004) }\end{array}$ \\
\hline Rice Straw & 71.70 & $\mathrm{a}$ & 17100 & 18.58 & 9.72 & Xiao et al. (2010) \\
\hline Pine Wood & 78.54 & 6.34 & 18600 & 14.66 & 0.46 & $\begin{array}{l}\text { Hassan et al. } \\
\text { (2009) }\end{array}$ \\
\hline Rice Hull & 61.00 & 1.90 & $\mathrm{a}$ & 24.00 & 13.00 & Teng et al. (1998) \\
\hline Oat Straw & 75.90 & 6.70 & 17000 & 0.10 & 17.30 & Ates et al. (20089 \\
\hline Beech & 73.62 & 7.03 & $\mathrm{a}$ & 19.11 & 0.24 & $\begin{array}{l}\text { Gómez et al. } \\
\text { (2009) }\end{array}$ \\
\hline Pine sawdust & 80.20 & 7.90 & $\mathrm{a}$ & 10.80 & 1.10 & $\begin{array}{l}\text { Guoxin et al. } \\
(2009)\end{array}$ \\
\hline Corn Cob & 71.80 & 8.64 & 16190 & 17.50 & 2.41 & Zhang et al. (2009) \\
\hline White Pine & 83.00 & 2.40 & $\mathrm{a}$ & 14.30 & 0.30 & Lin et al. (2010) \\
\hline White Oak & 85.90 & $\mathrm{a}$ & 8313 & 13.60 & 0.50 & Gaston (2011) \\
\hline
\end{tabular}

a Data is not available

Table 2. Proximate analysis of different type of biomass. 
Table 2 shows the proximate analysis and the calorific value of different materials. This set of analysis gives information on volatile matter (VM), ash and fixed carbon (FC) of a solid biofuels. VM and ash were experimentally quantified, while FC is determined by difference excluding the ash and moisture contents. The volatile content of a solid fuel is that portion released as a gas including moisture by thermogravimetry. VM and FC content provide the measure of chemical energy stored in a solid fuel.

Calorific value is a measure of heating power and is dependent on the composition of the biomass. CV refers to the amount of energy released when a known volume of gas is completely combusted under specified conditions. The significance of the calorific value is that the value provides the total energy content released when the fuel is burning in air. Therefore, CV represents the amount of energy potentially recovered from a given biomass.

\subsection{Yield of pyrolysis products}

As stated, pyrolysis is the process of the thermal decomposition of organic components in biomass in the absence of oxygen at various temperatures. Biomass can be converted to biochar and bio-oil (carbon rich solid residue and light gases), which can be used to supply the energy requirement of pyrolysis process operations (Bridgwater, 2004; Garcia-Perez et al., 2008a; 2008b). Biomass pyrolysis products are a complex combination of the products from the individual pyrolysis of cellulose, hemicellulose, lignin and extractives; each component has its own kinetic characteristics. In addition, secondary reaction products result from cross-reactions of primary pyrolysis products and reactions between pyrolysis products and the original feedstock molecules (Mohan et al., 2006).

Pyrolysis is one of the most thermally efficient processes to obtain liquid. The material balances of the pyrolysis products of different biomasses are given in Table 3.

At around $700{ }^{\circ} \mathrm{C}$, the weight loss of the orange peel pyrolysis was $78 \%$, wt., of which $20 \%$, wt. are light liquid hydrocarbons and $33.90 \%$, wt. is the heavy fraction, with $24.1 \%$, wt. as final residue and $22 \%$, wt. as non-condensable gases. Pyrolysis carried out at $750{ }^{\circ} \mathrm{C}$ results in the decrement of the char yield when the pyrolysis temperature increases, while the volatile content increases. From these results, it is evident that an appropriate selection of the heating rate, pyrolysis atmosphere and temperature will lead to more desirable end products. There is a good agreement between thermogravimetric weight loss data previously reported (Guevara, 2009; Miranda et al., 2009) and the data from the fixed bed reactor set-up. Therefore, these results will be helpful for designing and operating a pyrolysis plant of biomass. Bio-oil production converts up to $50-90 \%$, wt. of biomass energy into the liquid (Huber et al., 2006), which is favorable for fuel handling and transport.

Table 3 shows that yield and composition of pyrolysis products may vary depending on feedstock (Chiaramonti et al., 2007), reactor configurations and pyrolysis conditions (Lou et al., 2004; Bridgwater et al., 2007; Garcia-Perez et al., 2007a, 2007b). Low temperature and long volatiles residence time promote the production of biochar. A high temperature and long residence time increase the cracking of volatiles and, hence gas yield, while a moderate temperature and a short volatiles residence time are optimum for producing bio-oil (Bridgwater et al., 2007). On the other hand, biochar is a good alternative solid fuel for 
bioenergy production. Higher temperatures lead to lower char yield in all pyrolysis reactions, where the temperature is the main controlling variable of pyrolysis reaction kinetics (Antal \& Grønli, 2003).

\begin{tabular}{|c|c|c|c|c|c|c|}
\hline \multirow[t]{2}{*}{ Biomass } & \multirow[t]{2}{*}{ Reactor } & \multirow{2}{*}{$\begin{array}{l}\text { Temperature } \\
{ }^{\circ} \mathrm{C}\end{array}$} & \multicolumn{3}{|c|}{ Yield \%, wt. } & \multirow[t]{2}{*}{ Reference } \\
\hline & & & solid & Liquid & Gas & \\
\hline \multirow{2}{*}{$\begin{array}{l}\text { Orange } \\
\text { peel }\end{array}$} & \multirow{2}{*}{$\begin{array}{l}\text { Semi- } \\
\text { continuous }\end{array}$} & 700 & 22.0 & 53.9 & 24.1 & \multirow[t]{2}{*}{ Present work } \\
\hline & & 750 & 20.4 & 55.3 & 24.3 & \\
\hline \multirow{3}{*}{$\begin{array}{l}\text { Pecan } \\
\text { nutshell }\end{array}$} & \multirow{3}{*}{$\begin{array}{l}\text { Semi- } \\
\text { continuous }\end{array}$} & 600 & 28.0 & 49.2 & 22.8 & \multirow[t]{3}{*}{ Present work } \\
\hline & & 700 & 25.8 & 50.4 & 23.8 & \\
\hline & & 750 & 20.7 & 54.5 & 22.8 & \\
\hline Corn cob & Tubular & 600 & 24.0 & 34.0 & 42.0 & Cao et al. (2004) \\
\hline \multirow[t]{5}{*}{ Rice husk } & \multirow[t]{5}{*}{ Fluidized bed } & 400 & 33.0 & 46.5 & 6.5 & \multirow{5}{*}{$\begin{array}{l}\text { Williams \& } \\
\text { Nugranad } \\
(2000)\end{array}$} \\
\hline & & 450 & 32.0 & 43.5 & 10.0 & \\
\hline & & 500 & 29.0 & 37.0 & 17.5 & \\
\hline & & 550 & 26.8 & 28.5 & 25.4 & \\
\hline & & 600 & 25.5 & 21.5 & 34.5 & \\
\hline Olive pit & Batch & 600 & 29.0 & 18.0 & 53.0 & $\begin{array}{l}\text { Zabaniotou et } \\
\text { al. (2000) }\end{array}$ \\
\hline $\begin{array}{l}\text { Rice } \\
\text { straw }\end{array}$ & Free-fall & 800 & 84.3 & 1.0 & 14.7 & $\begin{array}{l}\text { Zanzi et al. } \\
(2002)\end{array}$ \\
\hline \multirow[t]{5}{*}{ Rice husk } & Fluidized bed & 420 & 35.0 & 53.0 & 12.0 & \multirow{5}{*}{$\begin{array}{l}\text { Zheng et al. } \\
(2006)\end{array}$} \\
\hline & & 450 & 29.0 & 56.0 & 15.0 & \\
\hline & & 480 & 24.0 & 56.0 & 20.0 & \\
\hline & & 510 & 21.0 & 33.0 & 26.0 & \\
\hline & & 540 & 18.0 & 49.0 & 33.0 & \\
\hline \multirow{6}{*}{$\begin{array}{l}\text { Almond } \\
\text { shell }\end{array}$} & Fixed bed & 300 & 47.3 & 41.3 & 11.4 & \multirow{6}{*}{$\begin{array}{l}\text { González et al. } \\
\text { (2005) }\end{array}$} \\
\hline & & 400 & 30.6 & 53.1 & 16.3 & \\
\hline & & 500 & 26.0 & 49.3 & 24.7 & \\
\hline & & 600 & 23.5 & 44.3 & 32.2 & \\
\hline & & 700 & 21.7 & 36.3 & 42.0 & \\
\hline & & 800 & 21.5 & 31.0 & 47.5 & \\
\hline \multirow{2}{*}{$\begin{array}{l}\text { Rice } \\
\text { straw }\end{array}$} & Fluidized bed & 400 & 23.0 & 57.0 & 20.0 & \multirow[t]{2}{*}{ Lee et al. (2005) } \\
\hline & & 412 & 32.0 & 50.0 & 18.0 & \\
\hline \multirow{2}{*}{$\begin{array}{l}\text { Pecan } \\
\text { nutshell }\end{array}$} & Not available & 480 & 17.0 & 23.0 & 50.0 & \multirow{2}{*}{$\begin{array}{l}\text { Manurung et al. } \\
\text { (2009) }\end{array}$} \\
\hline & & 400 & 33.0 & 44.0 & 23.0 & \\
\hline \multirow{4}{*}{$\begin{array}{l}\text { Physic } \\
\text { nutshell }\end{array}$} & Fixed bed & 500 & 45.0 & 30.0 & 25.0 & \multirow{4}{*}{$\begin{array}{l}\text { Sricharoenchaik } \\
\text { ul et al. (2008) }\end{array}$} \\
\hline & & 600 & 42.0 & 29.0 & 29.0 & \\
\hline & & 700 & 42.0 & 27.0 & 31.0 & \\
\hline & & 800 & 41.0 & 26.0 & 33.0 & \\
\hline
\end{tabular}

Table 3. Pyrolysis yields for various biomasses at different conditions. 


\subsection{Characterization of bio-oils}

Bio-oil is clean, cost-effective, $\mathrm{CO}_{2}$-neutral, and easy to transport and has low sulfur content, making biomass a dominant choice for the replacement of fossil fuels (Nader et al., 2009). Pyrolysis oils are composed of differently sized molecules, which are derived primarily from the de-polymerization and de-fragmentation reactions of the components of the original biomass, mainly cellulose, hemicellulose and lignin (Mohan et al., 2006; Neves et al., 2011). A chromatogram of the bio-oil orange dry peel pyrolysis is shown in Figure 3 , where the main peak is located at a retention time of $16.3 \mathrm{~min}$, which is identified as $\delta$-limonene. Table 4 and 5 show the composition of the liquid fractions obtained from the pyrolysis of orange peel and pecan nut shell by GC/MS (see Figures 3 and 4). Nearly, all the components are aromatic compounds. The molecular chains of complex compounds in the orange peel have been broken, generating compounds with a carbon number range of 6-16, see Table 4 .

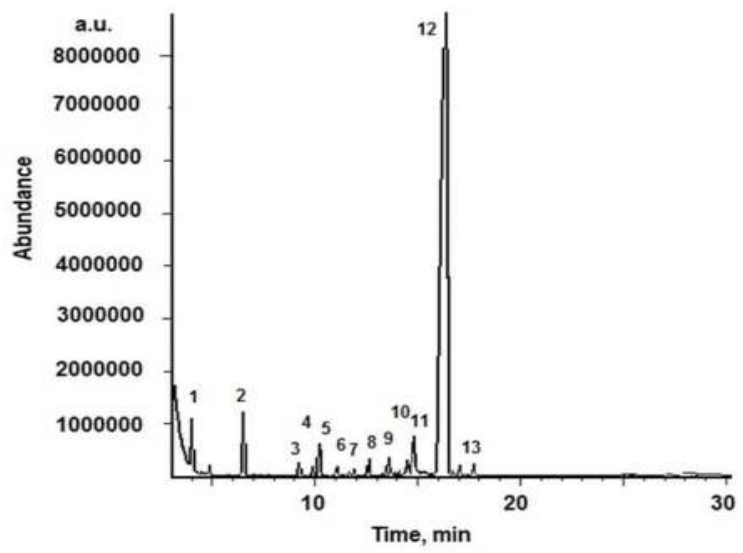

Figure 3. GC-MS spectrum of the bio-oil from dry orange peel pyrolysis bio-oil.

\begin{tabular}{|l|l|l|}
\hline Peak & Retention time, min & Identified Compound \\
\hline 1 & 4.00 & Benzene \\
\hline 2 & 5.53 & Toluene \\
\hline 3 & 9.43 & 2-methyl- 2-Hexanol \\
\hline 4 & 10.01 & Ethylbenzene \\
\hline 5 & 10.25 & $p$-Xylene \\
\hline 6 & 11.18 & Styrene \\
\hline 7 & 11.74 & 2-Cyclopenten-1-one,2-methyl- \\
\hline 8 & 12.35 & 1R-Pinene \\
\hline 9 & 13.57 & Benzene 1-ethyl-3-methyl- \\
\hline 10 & 14.68 & Phenol \\
\hline 11 & 14.83 & $\beta$-Pinene \\
\hline 12 & 16.30 & $\delta$-limonene \\
\hline 13 & 16.96 & Phenol, 2-methyl- \\
\hline 14 & 36.51 & n-Hexadecanoic acid \\
\hline
\end{tabular}

Table 4. Main components of bio-oil from orange peel pyrolysis identified by GC-MS. 


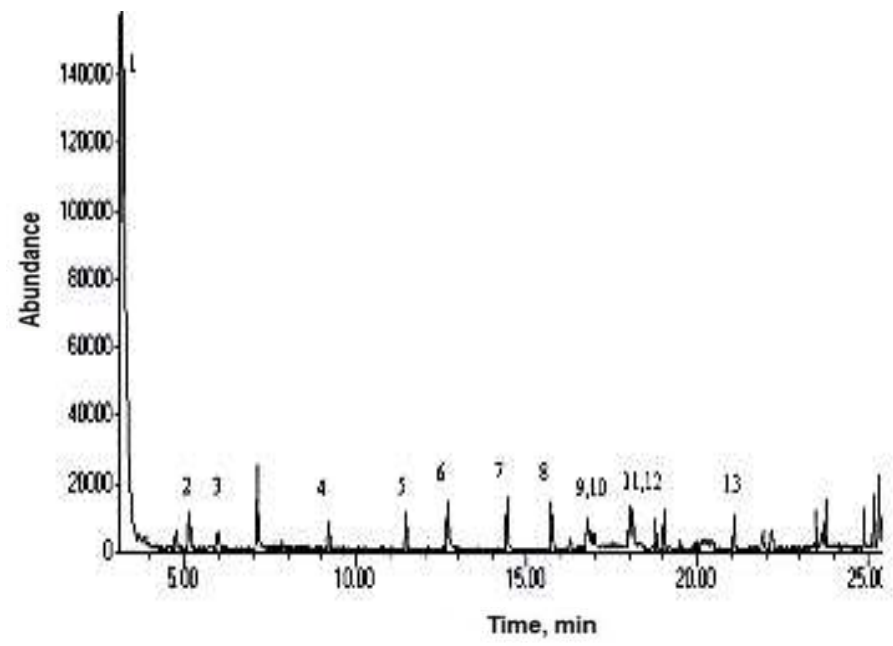

Figure 4. GC-MS spectrum of the bio-oil from dry nut shell pyrolysis bio-oil.

Pyrolysis oil from biomass is a red-brown liquid with $\mathrm{pH} 3$ and 4 . Table 7 reports the properties of the pyrolitic oil from both biomasses under study. The oil contains the defragmented parts of the oxygenated components of the original biomass structure (mainly cellulose, hemicellulose and lignin). The bio-oil contains oxygen in the range of of $28-40 \%$, wt. oxygen on a dry basis. The bio-oil (i.e., organic phase) has 32 to 42 heating value (MJ/kg) $\mathrm{HHV}$, which is low heating value with respect to fossil fuels. Similar results are reported by literature (Diebold, 2000; Czernik \& Bridgwater, 2004; Oasmaa \& Meier, 2005; Oasmaa et al., 2005).

\begin{tabular}{|l|l|l|}
\hline Peak & Retention Time, min & Identified compound \\
\hline 1 & 3.144 & Benzene, 1,3-bis(3-phenoxyphenoxy)- \\
\hline 2 & 5.124 & Toluene \\
\hline 3 & 5.953 & 2-Pentanone, 3-methylene- \\
\hline 4 & 9.221 & Benzene, (1-methylethyl)- \\
\hline 5 & 11.487 & Limonene \\
\hline 6 & 12.677 & Phenol, 2-methoxy- \\
\hline 7 & 14.422 & Phenol, 2-methoxy-4-methyl- \\
\hline 8 & 15.732 & Phenol, 4-ethyl-2-methoxy- \\
\hline 9 & 16.264 & 2-Methoxy-4-vinylphenol \\
\hline 10 & 16.762 & Phenol, 2,6-dimethoxy- \\
\hline 11 & 18.095 & Phenol, 2-methoxy-4-(1-propenyl)- \\
\hline 12 & 18.799 & Phenol, 2,4-bis(1,1-dimethylethyl)- \\
\hline 13 & 21.088 & Phenol, 2,6-dimethoxy-4-(2-propenyl)- \\
\hline
\end{tabular}

Table 5. Main components of bio-oil from nut shell pyrolysis identified by GC-MS. 


\begin{tabular}{|l|l|l|}
\hline Properties of pyrolytic oil & Nut shell & Orange peel \\
\hline Water content (\%-wt.) & 30 & 35 \\
\hline Acidity (pH) & 3 & 4 \\
\hline Elemental composition $(\%, w t)$. & & \\
C & 62.40 & 53.90 \\
$\mathrm{H}$ & 8.42 & 6.00 \\
$\mathrm{O}$ & 28.72 & 40.0 \\
$\mathrm{~N}$ & 0.30 & 0.10 \\
\hline Ash content $(\%, \mathrm{wt})$. & 0.10 & 0.10 \\
\hline Heating value $(\mathrm{MJ} / \mathrm{kg}) \mathrm{HHVa}$ & 32.98 & 42.70 \\
\hline a HHV from organic fraction &
\end{tabular}

Table 6. Properties of pyrolysis bio-oils from nutshell and orange peel.

Pyrolysis liquids are formed by rapidly and simultaneously depolymerizing and fragmenting cellulose, hemicellulose, and lignin with a rapid increase in temperature followed by a condensation system in order to collect all condensable volatiles. If the residence time at high temperature was extended, many products would further react (degrade, cleave, or condensate with other molecules). Bio-oils contain many reactive species, which contribute to unusual attributes (Mohan et al., 2006). Chemically, bio-oil is a complex mixture of components and is difficult to analyze and characterize. Different classes of chemicals are reported in literature such as: water, guaiacols, catecols, syringols, vanillins, furancarboxaldehydes, isoeugenol, pyrones, acetic acid, formic acid, and other carboxylic acids. Bio-oil also contains other major groups of compounds, including hydroxyaldehydes, hydroxyketones, sugars, carboxylic acids, and phenolics. Oligomeric species in bio-oil are derived mainly from lignin, but also from cellulose (Mohan et al., 2006; Oasmaa et al., 2005).

Due to the presence of large amounts of (potentially) highly reactive components, the bio-oil is unstable and tends to separate and forms solids upon storage. Phase separation is promoted by higher temperatures and appears to be faster when the amount of water in the oil is low. Severe polymerization of the oil will result in the formation of char. Distillation also causes undesirable chemical changes leading to the formation of large amounts of solid material. The non- condensable gas products obtained by biomass under study are a mixture of carbon dioxide, carbon monoxide, hydrogen, methane and small amounts of other lighter hydrocarbons, similar to those reported in literature (Bridgwater et al., 1999; Bridgwater \& Peacocke, 2000).

\section{Conclusion}

Pecan nut shell and orange peel are excellent feedstocks for production of energy and value-added products. Biomass residues store a large amount of energy, which can be converted to several forms of usable energy through a number of commercially available processes. Pyrolysis is believed to be the reasonable choice to convert orange peel and pecan nut shell residues to liquid fuels, biocha, and activated carbons. The biomass solid waste in the form of pecan nut shell and orange peel is successfully converted into liquid, char and gas by fixed bed pyrolysis system. The heating value of the pyrolysis oil is found to be 32.98 
$\mathrm{MJ} / \mathrm{kg}$ for pecan nut shell and $42.70 \mathrm{MJ} / \mathrm{kg}$ for orange peel bio-oil, which is higher than other biomass-derived pyrolysis oils and also significantly higher than that obtained for the original waste. The maximum liquid yield is found to be $55.3 \%$, wt. and $54.5 \mathrm{wt} \%$ of dry biomass feedstock at the temperature range of $700-750^{\circ} \mathrm{C}$ and $600-750^{\circ} \mathrm{C}$ for orange peel and pecan nut shell, respectively. The oil from the biomass under study may be considered as an important important potential potential source of alternative fuel. A lot of research and development process will be necessary in this topic. However, this will occur with greater economic incentive and the climate change regulation will promote research activities in this direction.

\section{Acknowledgments}

The authors gratefully acknowledge the support of the Chemical Engineering Department of the UANL and CONACYT (México).

\section{References}

[1] Abdel-Nasser, A. \& El-Hendawy (2005). Surface and adsorptive properties of carbon prepared from biomass. Applied Surface Science, Vol. 252, No. 2, (October 2005), pp. (287295), ISSN 0169-4332.

[2] Ahmad, A.L., Loh, M.M. \& Aziz, J.A. (2006). Preparation and characterization of activated carbon from oil palm wood and its evaluation on methylene blue adsorption. Dye and Pigments, Vol. 75, No. 2, (2007), pp. (263-272), ISSN 0143-7208.

[3] Antal, M.J. \& Grønli, M. (2003). The art, science and technology of charcoal production. Industrial and Engineering Chemistry Research, Vol. 42, No. 8, (March 2003), pp. (16191640), ISSN: 0140-6701.

[4] Ates, F. \& Işikdağ, M.A. (2008). Evaluation of the role of the pyrolysis temperature in straw biomass samples and characterization of the oils by GCMS. Energy $\mathcal{E}$ Fuels, Vol. 22, No. 3, (April 2008), pp. (1936-1943), ISSN 1520-5029.

[5] Balci, S., Dogu, T. \& Yucel, H. (1993). Pyrolysis kinetics of lignocellulosic materials. Industrial \&Engineering Chemistry Research, Vol. 32, No. 11, (November, 1993), pp. (25732579), ISSN 08885885.

[6] Baquero, M.C., Giraldo, L., Moreno, J.C., Suárez-García, F., Martínez-Alonso, A. \& Tascón, J.M.D. (2003). Activated carbons by pyrolysis of coffee bean husks in presence of phosphoric acid. Journal of Analytical and Applied Pyrolysis, Vol. 70, No. 2, (December 2003), pp. (779-784), ISSN 0165-2370.

[7] Baxter, L.L. (1993). Ash deposition during biomass and coal combustion: A mechanistic approach. Biomass and Bioenergy, Vol. 4, No. 2, (1993), pp. (85-102), ISSN 0961-9534.

[8] Bonelli, P.R., Cerrella, E.G. \& Cukierman, A.L. (2003). Slow pyrolysis of nutshells: Characterization of derived chars and of process kinetics. Energy Sources, Vol. 25, No. 8, (Jun 2003), pp. (767-778), ISSN 0090-8312.

[9] Bridgwater, A.V., Carson, P. \& Coulson, M. (2007). A comparison of fast and slow pyrolysis liquids from mallee. International Journal of Global Energy Issues, Vol. 27, No. 2, pp. (204-216), ISSN 1741-5128.

[10] Bridgwater, A. V. (2004). Biomass Fast Pyrolysis. Thermal Science, Vol. 8, No. 2, (November 2004), pp. (21-49), ISSN 0354-9836. 
[11] Bridgwater, A.V. \& Peacocke, G.V.C. (2000). Fast Pyrolysis Processes for Biomass. Renewable and Sustainable Energy Reviews, Vol. 4, No. 1, (March 2000), pp. (1-73), ISSN 1364-0321.

[12] Bridgwater, A.V., Meier, D. \& Radlein, D. (1999). An overview of fast pyrolysis of biomass. Organic Geochemistry, Volume 30, No. 12, (December 1999), pp. (1479-1493), ISSN 0146-6380.

[13] Budinova, T., Ekinci, E., Yardin, F., Grimm, A., Björnbom, E., Minkova, V. \& Goranova, M. (2006). Characterization and application of activated carbon produced by $\mathrm{H}_{3} \mathrm{PO}_{4}$ and water vapour activation. Fuel Processing Technology, Vol. 87, No. 10, (October 2006), pp. (899-905), ISSN 0378-3820.

[14] Cao, Q., Xie, K-C., Bao, W-R. \& Shen, S-G. (2004). Pyrolytic behavior of waste corn cob. Bioresource Technology, Vol. 94, No. 1, (August 2004), pp. (83-89), ISSN 0960-8524.

[15] Chiaramonti, D., Oasmaa, A. \& Solantausta, Y. (2007). Power generation using fast pyrolysis liquids from biomass, Renewable and Sustainable Energy Reviews. Vol. 11, No. 6, (August 2007), pp. (1056-1086), ISSN 1364-0321.

[16] Czernik, S. \& Bridgwater, A.V. (2004). Overview of Applications of Biomass Fast Pyrolysis Oil. Energy \& Fuels, Vol. 18, No.2, (February, 2004), pp. (590-598), ISSN 15205029.

[17] Das, P., Ganesh, A. \& Wangikar, P. (2004). Influence of pretreatment for deashing of sucarcane bagasse on pyolysis products. Biomass and Bioenergy, Vol. 27, No. 5, (November 2004), pp. (445-457), ISSN 0961-9534.

[18] Demirbas, A. (2006). Effect of temperature on pyrolysis products from four nut shells. Journal of Analytical and Applied Pyrolysis, Vol. 76, No. 1-2, (June 2006), pp. (285-289), ISSN 0165-2370.

[19] Diebold, J. P.(2000). Review of the Chemical and Physical Mechanisms of the Storage Stability of Fast Pyrolysis Bio-Oils. National Renewable Energy Laboratory, (January 2000). NREL/SR-570-27613.

[20] Durán-Valle, C.J., Gómez-Corzo, M., Pastor-Villegas, J. \& Gómez-Serrano, V. (2005). Study of cherry stone as raw material in preparation of carbonaceous adsorbents. Journal of Analytical and Applied Pyrolysis, Vol. 73, No. 1, (March 2005), pp. (59-67), ISSN 0165-2370.

[21] Fagbemi, L., Khezami, L. \& Capart, R. (2001). Pyrolysis products from different biomasses: application to the thermal cracking of tar. Applied Energy, Vol. 69, No. 4, (293-306), pp. (293-306), ISSN 0306-2619.

[22] Garcia-Perez, M., Adams, T.T., Goodrum, J.W., Geller, D.P. \& Das, K.C. (2007b). Production and Fuel Properties of Pine Chip Bio-oil/Biodiesel Blends. Energy \& Fuels, Vol. 21, No. 4, (May 2007), pp. (2363-2372), ISSN 1520-5029.

[23] Garcia-Perez, M., Chaala, A., Pakdel, H., Kretschmer, D. \& Roy, D. (2007a). Vacuum pyrolysis of softwood and hardwood biomass: Comparison between product yields and bio-oil properties. Journal of Analytical and Applied Pyrolysis, Vol. 78, No. 1, (January 2007), pp. (104-116), ISSN 0165-2370.

[24] Garcia-Perez, M., Wang, S., Shen, J., Rhodes, M., Lee, W.J. \& Li, C.Z. (2008a). Effects of Temperature on the Formation of Lignin-Derived Oligomers during the Fast Pyrolysis of Mallee Woody Biomass. Energy \& Fuels, Vol. 22, No. 3, (March 2008), pp. (2022-2032), ISSN 1520-5029. 
[25] Garcia-Perez, M., Wang, X.S., Shen, J., Rhodes, M.J., Tian, F., Lee, W.J., Wu, H. \& Li, C.Z. (2008b). Fast Pyrolysis of Oil Mallee Woody Biomass: Effect of Temperature on the Yield and Quality of Pyrolysis Products. Industrial and Engineering Chemical Research, Vol. 47, No. 6, (March 2008), pp. (1846-1854), ISSN 1520-5045.

[26] Gaston, K.R., Jarvis, M.W. Pepiot, P., Smith, K.M., Frederick, W.J. \& Nimlos, M.R. (2011). Biomass pyrolysis and gasification of varying particle sizes in a fluidized bed reactor. Energy \& fuels, Vol. 25, No. 8, (August 2011), pp. (3747-3757), ISSN 1520-5029.

[27] Giuntoli, J., Arvelakis, S., Spliethoff, H., de-Jong, W. \& Verkooijen, A.H.M. (2009). Quantitative and kinetic thermogravimetric Fourier Transform Infrares (TG-FTIR) study of pyrolysis of agricultural residues. Influence of different pretreatments. Energy \& Fuels, Vol. 23, No. 11, (August 2009), pp. (5695-5706), ISSN 08870624.

[28] Gómez, C., Velo, E., Barontini, F. \& Cozzani, V. (2009). Influence of secondary reactions on the heat of Pyrolysis of biomass. Industrial and Engineering Chemical Research, Vol. 48, No. 23, (December 2009), pp. (10222-10233), ISSN 1520-5045.

[29] González, J. F., Ramiro, A., González-García, C. M., Gañan, J., Encinar, J.M, Sabio, E. \& Rubiales, J. (2005). Pyrolysis of Almond Shells. Energy Applications of Fractions. Industrial and Engineering Chemical Research, Vol. 44, No. 9, (March 2005), pp. (30033012), ISSN 0888-5885.

[30] Guevara, K., Miranda, R., Sosa, C. \& Rodríguez, M. (2009). Obtención de BioCombustibles Mediante Pirólisis De Cáscara De Nuez Pecanera. Revista Salud Pública y Nutrición, Vol. 47, No. 1-2010, (Septiembre 2009), Edición especial, ISSN 1870-0160.

[31] Guoxin, H., Hao, H. \& Yanhong, L. (2009). Hydrogen-rich gas production from pyrolysis of biomass in an autogenerated steam atmosphere. Energy \& Fuels, Vol. 23, No. 3, (March 2009), pp. (1748-1753), ISSN 1520-5029.

[32] Hassan, el-B.M., Steele, P.H. \& Ingram, L. (2009). Characterization of fast pyrolysis biooils produced from pretreated pine wood. Applied Biochemistry and Biotechnology, Vol. 154, No. 1, (May 2009), pp. (3-13), ISSN 1559-0291.

[33] Heikkinen, J.M., Hordijk, J.C., de-Jong, W. \& Spliethoff, H. (2004). Thermogravimetry as a tool to classify waste component to be used for energy generation. Journal of Analytical and Applied Pyrolysis, Vol. 71, No. 2, (June 2004), pp. (883-900), ISSN 0165-2370.

[34] Huber, G.W., Iborra, S. \& Corma, A. (2006). Synthesis of Transportation Fuels from Biomass. Chemistry, Catalysts, and Engineering, Chemical Reviews, Vol. 106, No. 9, (June 2006), pp. (4044-4098), ISSN 4044-4098.

[35] Lee, K-H., Kang, B-S., Park, Y-K. \& Kim, J-S. (2005). Influence of Reaction Temperature, Pretreatment, and a Char Removal System on the Production of Bio-oil from Rice Straw by Fast Pyrolysis, Using a Fluidized Bed. Energy \& Fuels, Vol. 19, No. 5, (May 2005), pp. (2179-2184), ISSN 0887-0624.

[36] Li, D., Chen, L., Zhang, X., Ye, N. \& Xing, F. (2011). Pyrolytic characteristics and kinetic studies of three kinds of red algae. Biomass and Bioenergy, Vol. 35, No. 5, (May 2011), pp. (1765-1772), ISSN 0961-9534.

[37] Lin, Y., Zhang, C., Zhang, M. \& Zhang, J. (2010). Deoxygenation of bio-oil during pyrolysis of biomass in the presence of $\mathrm{CaO}$ in a fluidized-bed reactor. Energy $\&$ fuels, Vol. 24, No. 11, (September 2010), pp. (5686-5695), ISSN 1520-5029.

[38] Lozano-Castello, D., Alcaniz-Monge, J., Cazorla-Amoros, D., Linares-Solano, A., Zhu, W., Kapteijn, F. \& Moulijn, J.A. (2005). Adsorption properties of carbon molecular sieve 
prepared from an activated carbon at pitch pyrolysis. Carbon, Vol. 43, No. 8, (July 2005), pp. (1643-1651), ISSN 0008-6223.

[39] Lua, A.C., Yang, T. \& Guo, J. (2004). Effects of pyrolysis conditions on the properties of activated carbons prepared from pistachio-nut shells. Journal of Analytical and Applied Pyrolysis, Vol. 72, No. 2, (November 2004), pp. (279-287), ISSN 0008-6223.

[40] Luo, Z., Wang, S., Liao, Y., Zhou, J., Gu, Y. \& Cen, K. (2004). Research on biomass fast pyrolysis for liquid fuel. Biomass and Bioenergy, Vol. 26, No. 5, (May 2004), pp. (455-462), ISSN 0961-9534.

[41] Manurung, R., Wever, D.A.Z., Wildschut, J., Venderbosch, R.H., Hidayat, H., Van Dam, J.E.G., Leijenhorst, E.J., Broekhuis, A.A. \& Heeres, H.J. 2009. Valorisation of Jatropha curcas L. plant parts: Nut shell conversion to fast pyrolysis oil. Food and Bioproducts Processing, Vol. 87, No. 3, (September 2009), pp. (187-196), ISSN 0960-3085.

[42] Mehandjiev, D.R., Nickolov, R.N. \& Ioncheva, R.B. (1997). Determination of nitrogen structures on activated carbon surfaces by a chemical method. Fuel, Vol. 76, No. 5, (April 1997), pp. (381-384), ISSN 0016-2361.

[43] Miranda, R., Bustos-Martínez, D., Sosa-Blanco, C., Gutiérrez-Villareal, M.H. \& Rodríguez-Cantú, M.E. (2009). Pyrolysis of sweet orange (Citrus sinensis) dry peel. Journal of Analytical and Applied Pyrolysis, Vol. 86, No. 2, (November 2009), pp. (245-251), ISSN 0165-2370.

[44] Mohan, D., Pittman, C.U. \& Steele, P.H. (2006). Pyrolysis of Wood/Biomass for Bio-oil: A Critical Review. Energy and Fuels, Vol. 20, No. 3, (March 2006), pp. (848-889), ISSN 0887-0624.

[45] Nader, M., Pulikesi, M., Thilakavathi, M. \& Renata, R. (2009). Analysis of bio-oil, biogas, and biochar from pressurized pyrolysis of wheat straw using a tubular reactor. Energy Fuels Vol 23, No. 1, pp. (2736-2742), ISSN 1520-5029.

[46] Neves, D., Thunman, H., Matos, A., Tarelho, L. \& Gómez-Barea, A. (2011). Characterization and prediction of biomass pyrolysis products. Progress in Energy and Combustion Science, Vol. 37, No. 5, (September 2011), pp. (611-630), ISSN 0360-1285.

[47] Nickolov, R.N. \& Mehandjiev, D.R. (1995). Application of the Simplified equation for micropore size distribution to the study of water vapour adsorption on activated carbon. Adsorption Science and Technology, Vol 12, No.3, pp. (203-209), ISSN 0263-6174.

[48] Oasmaa, A. \& Meier, D. (2005). Norms and Standards for Fast Pyrolysis Liquids - 1. Round Robin Test. Journal of Analytical and Applied Pyrolysis, Vol. 73, No. 2, (June 2005), pp. (323-334), ISSN 0165-2370.

[49] Oasmaa, A.; Peacocke, C., Gust, S., Meier, D. \& McLellan, R. (2005). Norms and Standards for Pyrolysis Liquids. End-user Requirements and Specifications. Energy $\mathcal{E}$ Fuels, Vol. 19, No. 5, (August 2005), pp. (2155-2163), ISSN 0887-0624.

[50] Onay, O., Beis, S.H. \& Kockar, O.M. (2004). Pyrolysis of walnut shell in a well-swept fixed-bed reactor. Energy Sources, Vol. 26, No. 8, (June 2004), pp. (771-82), ISSN: 03605442.

[51] Özbay, N., Pütün, A.E., Uzun, B.B. \& Pütün, E. (2001). Biocrude from biomass: pyrolysis of cottonseed cake. Renewable Energy. Vol 24, No. 3-4, (November 2001), pp. (615-625), ISSN: 1364-0321.

[52] Prakash, N. \& Karunanithi, T. (2008). Kinetic Modeling in Biomass Pyrolysis - A Review. Journal of Applied Sciences Research, Vol. 4, No. 12, pp. (1627-1636), ISSN 1819544X 
[53] Pütün, A.E., Apaydin, E. \& Pütün, E. (2004). Rice Straw as a bio-oil source via pyrolysis and steam pyrolysis. Energy, Vol. 29, No. 12-15, (October-December 2004), pp. (21712180), ISSN 0360-5442.

[54] Raveendran, K., Ganesh, A. \& Khilar, K.C. (1996). Pyrolysis characteristics of biomass and biomass components. Fuel, Vol. 75, No. 8, (June 1996), pp. (987-98), ISSN 0016-2361.

[55] Ren, Q., Zhao, C., Wu, X., Liang, C., Chen, X., Shen, J., Tang, G. \& Wang, Z. (2009) Effect of mineral matter on the formation of NOx precursors during biomass pyrolysis. Journal of Analytical and Applied Pyrolysis, Vol. 85, No. 1-2, (May 2009), pp. (447-53), ISSN 00086223.

[56] Safi, M.J., Mishra, I.M. \& Prasad, B. (2004). Global degradation kinetics of pine needles in air. Thermochimica Acta, Vol. 412, No.1-2, (March 2004), pp.(155-62), ISSN 0040-6031.

[57] Sircar, S., Golden, T.C. \& Rao, M.B. (1996). Activated carbon for gas separation and storage. Carbon, Vol. 34, No. 1, pp. (1-12), ISSN 0008-6223.

[58] Sricharoenchaikul, V., Pechyen, C., Aht-ong \& Atong, D. Preparation and Characterization of Activated Carbon from the Pyrolysis of Physic Nut (Jatropha curcas L.) Waste. Energy \& Fuels, Vol. 22, No. 1, (September 2007), pp. (31-37), ISSN 0887-0624.

[59] Sudiro, M. \& Bertucco, A. (2007). Synthetic Fuels by a Limited CO2 Emission Process Which Uses Both Fossil and Solar Energy. Energy \& Fuels, Vol. 21, No. 6, pp. (36683675), ISSN 08870624.

[60] Teng, H. \& Wei, Y.C. (1998). Thermogravimetric studies on the kinetics of rice hull pyrolysis and the influence of water pretreatment. Industrial and Engineering Chemical Research, Vol. 37, No. 10, (September 1998), pp. (3806-3811), ISSN 1520-5045.

[61] Van-Krevelen, D.W. (1950). Graphical-statistical method for the study of structure and reaction processes of coal. Fuel, Vol. 29, No. 1, pp. (269-84), ISSN 0016-2361.

[62] Williams, P.T \& Nugranad, N. (2000). Comparison of products from the pyrolysis and catalytic pyrolysis of rice husks. Energy, Vol. 25, No. 6, (June 2000), pp. (493-513), ISSN 0360-5442.

[63] Xiao, R., Chen, X., Wang, F. \&Yu, G. (2010). Pyrolysis pretreatment of biomass for entrained-flow gasification. Applied Energy, Vol. 87, No. 1, (January 2010), pp. (149-155), ISSN 0306-2619.

[64] Yanik, J., Kornmayer, C., Saglam, M. \& Yüksel, M. Fast Pyrolysis of agricultural wastes: characterization of pyrolysis products. (2007). Fuel processing technology, Vol. 88, No. 10, (October 2007), pp. (942-947), ISSN 0378-3820.

[65] Zabaniotou, A.A., Roussos, A. \& Koroneos, C. (2000). A laboratory study of cotton gin waste pyrolysis. Journal of Analytical and Applied Pyrolysis, Vol. 56, No. 1, (September 2000), pp. (47-59), ISSN 0165-2370.

[66] Zanzi, R., Sjöström, K. \& Björnbom, E. (2002). Rapid pyrolysis of agricultural residues at high temperature. Biomass and Bioenergy, Vol. 23, No. 5, (November 2002), pp. (357-366), ISSN 0961-9534.

[67] Zhang, H., Xiao, R., Wang, D., Zhong, Z., Song, M., Pan, Q. \& He, G. (2009). Catalytic fast pyrolysis of biomass in a fluidized bed with fresh and spent fluidized catalytic cracking (FCC) catalysts. Energy \& Fuels, Vol. 23, No. 12, (December 2009), pp. (61996206), ISSN 1520-5029.

[68] Zheng, J-L., Zhu, X-F., Guo, Q-X. \& Zhu, Q-S. (2006). Thermal conversion of rice husks and sawdust to liquid fuel. Waste Management, Vol. 26, No. 12, (January 2006), pp. (14301435), ISSN 0956-053X. 


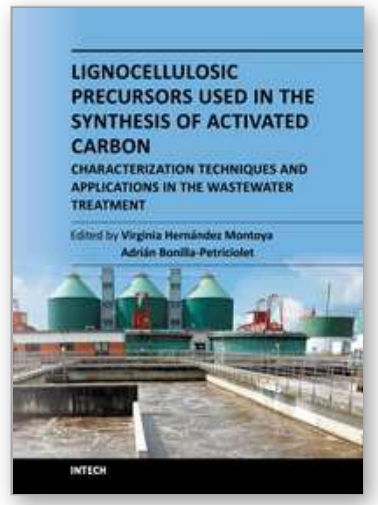

\author{
Lignocellulosic Precursors Used in the Synthesis of Activated \\ Carbon - Characterization Techniques and Applications in the \\ Wastewater Treatment \\ Edited by Dr. Virginia Hernández Montoya
}

ISBN 978-953-51-0197-0

Hard cover, 92 pages

Publisher InTech

Published online 29, February, 2012

Published in print edition February, 2012

The present book discusses the principal lignocellulosic precursors used in the elaboration of activated carbons in different countries such as Asia, America, Europe and Africa; the different methods and experimental conditions employed in the synthesis of activated carbons, including one analysis of the principal stages of the preparation such as carbonization and activation (i.e., chemical or physical activation). Also, the recent and more specialized techniques used in the characterization of activated carbons are discussed in this book. For example, the techniques employed to determine textural parameters (mercury porosimetry and gas adsorption isotherms at $77 \mathrm{~K}$ ) and different spectroscopies to determine chemical functionality (Raman, FT-IR, etc.) and other X-Ray techniques. Additionally, an overview of the application of activated carbons obtained from lignocellulosic precursors for wastewater treatment. Specifically, the analysis and discussion are focused on the advantages and capabilities of activated carbons for the removal of relevant toxic compounds and pollutants from water such as heavy metals, dyes, phenol, etc. Finally, the use of pyrolysis method for the valorization of two Mexican typical agricultural wastes (orange peel and pecan nut shell) for energy and carbon production is considered in this book.

\title{
How to reference
}

In order to correctly reference this scholarly work, feel free to copy and paste the following:

Rosa Miranda, César Sosa, Diana Bustos, Eileen Carrillo and María Rodríguez-Cantú (2012). Characterization of Pyrolysis Products Obtained During the Preparation of Bio-Oil and Activated Carbon, Lignocellulosic Precursors Used in the Synthesis of Activated Carbon - Characterization Techniques and Applications in the Wastewater Treatment, Dr. Virginia Hernández Montoya (Ed.), ISBN: 978-953-51-0197-0, InTech, Available from: http://www.intechopen.com/books/lignocellulosic-precursors-used-in-the-synthesis-of-activated-carboncharacterization-techniques-and-applications-in-the-wastewater-treatment/no-title-specified-4

\section{INTECH}

open science | open minds

\author{
InTech Europe \\ University Campus STeP Ri \\ Slavka Krautzeka 83/A \\ 51000 Rijeka, Croatia \\ Phone: +385 (51) 770447 \\ Fax: +385 (51) 686166
}

\author{
InTech China \\ Unit 405, Office Block, Hotel Equatorial Shanghai \\ No.65, Yan An Road (West), Shanghai, 200040, China \\ 中国上海市延安西路65号上海国际贵都大饭店办公楼 405 单元 \\ Phone: +86-21-62489820 \\ Fax: +86-21-62489821
}


www.intechopen.com 
(C) 2012 The Author(s). Licensee IntechOpen. This is an open access article distributed under the terms of the Creative Commons Attribution 3.0 License, which permits unrestricted use, distribution, and reproduction in any medium, provided the original work is properly cited. 